\title{
DCP-LA Exerts an Antiaging Action on the Skin
}

\author{
Tomoyuki Nishizaki \\ Innovative Bioinformation Research Organization, Kobe, Japan
}

\section{Key Words \\ Aged skin · Antiaging $\cdot$ DCP-LA $\cdot$ NO stress · \\ Senescence-associated $\beta$-galactosidase}

\begin{abstract}
The present study assessed the possibility for the linoleic acid derivative 8-[2-(2-pentyl-cyclopropylmethyl)-cyclopropyl]octanoic acid (DCP-LA) as an antiaging compound for the skin by assaying senescence-associated $\beta$-galactosidase (SA$\beta-G a l)$, a biomarker of senescence and cell viability. The nitric oxide (NO) donor sodium nitroprusside (SNP) increased in SA- $\beta$-Gal-positive cells in cultured human fibroblasts and mouse keratinocytes, and DCP-LA significantly inhibited the effect of SNP. Moreover, SNP induced cell death in cultured mouse keratinocytes, and DCP-LA significantly prevented NO stress-induced death of keratinocytes. Taken together, these results indicate that DCP-LA exerts an antiaging action on the skin.

(c) 2016 S. Karger AG, Basel
\end{abstract}

\section{Introduction}

Skin aging is classified into two types: natural aging, which results from the passage of time, and photoaging, which results from habitual ultraviolet (UV) exposure [1, 2]. The latter is superimposed on intrinsic aging, and both natural aging and photoaging are cumulative. Of the factors responsible for facilitating skin aging, oxidative stress plays a critical role. Oxidative stress is induced by reactive oxygen species (ROS) and reactive nitrogen species (RNS), which are produced in the normal cellular redox process [3]. UV exposure enhances ROS/RNS production [4-6], and the free radicals cause skin damage including apoptosis by interacting with DNAs, RNAs, and proteins [7]. Several lines of evidence have pointed to the implication of mitogen-activated protein kinase, aryl hydrocarbon receptor, transcription factors, such as nuclear factor$\kappa \mathrm{B}$ and nuclear factor erythroid 2-related factor 2, or matrix metalloproteinase in the degradation of dermal connective tissue following oxidative stress-induced skin damage [8-15].

Senescence-associated $\beta$-galactosidase (SA- $\beta$-Gal) has been proposed as a biomarker of senescence [16]. Overexpression and accumulation of endogenous lysosomal $\beta$-Gal is found specifically in senescent cells [17]. $\beta$-Gal hydrolyzes $\beta$-galactosides into monosaccharides. The quantitative $\beta$-Gal assay using X-Gal, a substrate, was devised, where senescent cells contain blue-dyed precipitate $[18-20]$. The assay is widely used to assess cell senescence, although expression of $\beta-\mathrm{Gal}$ is not required for senescence.

A variety of skin care products and food supplements which exhibit an antioxidant effect have been produced. We have earlier synthesized the linoleic acid derivative

Dr. Tomoyuki Nishizaki

Innovative Bioinformation Research Organization

2-3-14 Katsuragi, Kita-ku

Kobe 651-1223 (Japan)

E-Mail tnishizaki@bioresorganization.com 


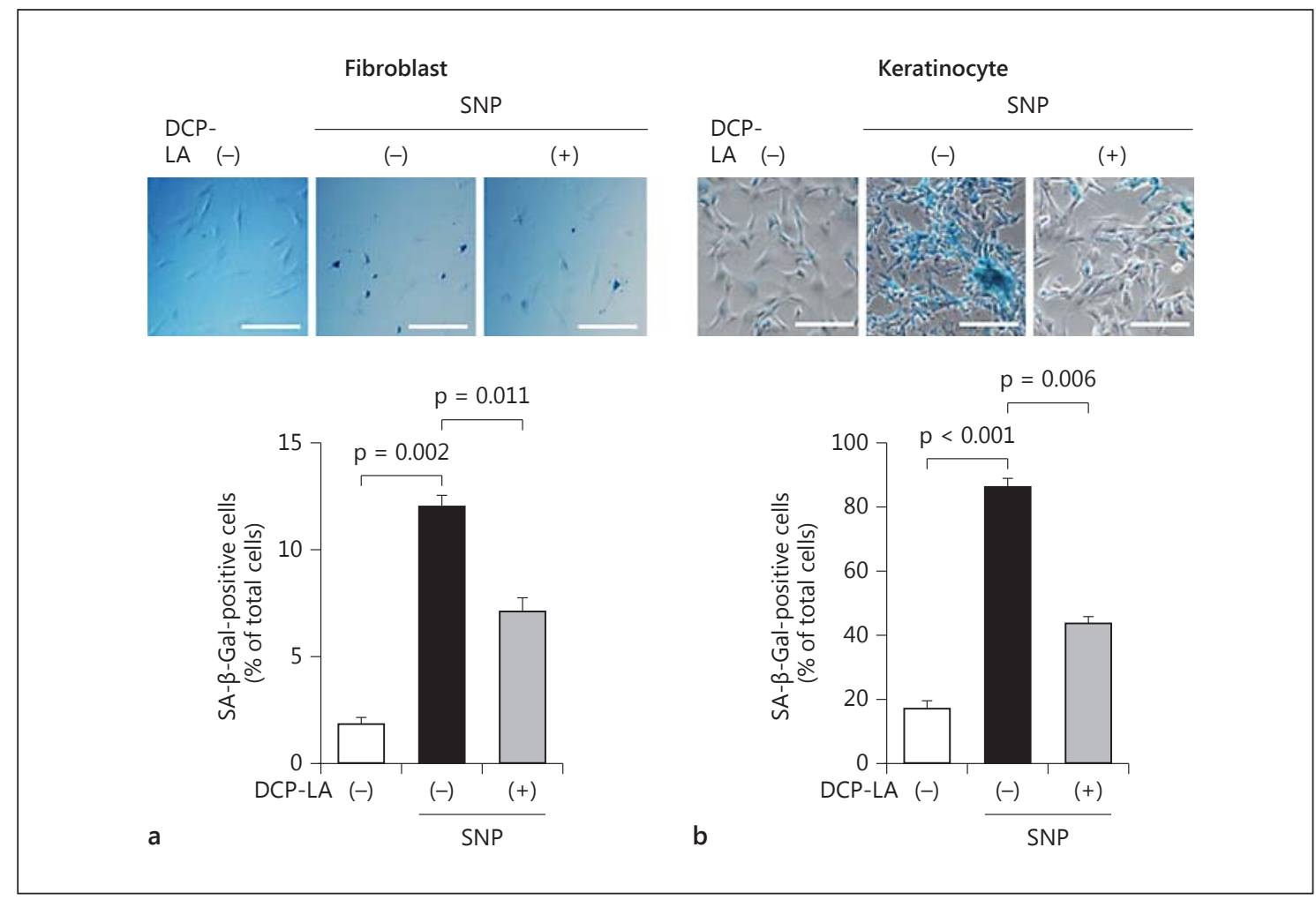

Fig. 1. DCP-LA inhibits SNP-induced increase in SA- $\beta$-Gal-positive cells. Cultured human fibroblasts (a) or mouse keratinocytes (b) were treated with DCP-LA $(100 \mathrm{nM})$ in the presence and absence of SNP (1 mM) for $24 \mathrm{~h}$, followed by SA- $\beta$-Gal staining. In the graphs, each column represents the mean $( \pm$ SEM) percentage of SA$\beta$-Gal-positive cells against the number of total cells $(n=4$ independent experiments). $p$ values: Dunnett's test.

8-[2-(2-pentyl-cyclopropylmethyl)-cyclopropyl]-octanoic acid (DCP-LA), which contains cyclopropane rings instead of cis-double bonds on linoleic acid. We have found that DCP-LA inhibits oxidative stress-induced apoptosis of neurons by inhibiting caspase-3/-9 activation [21]. Then, we were prompted to assess the effect of DCP-LA on oxidative stress-induced skin damage. The results of the present study demonstrate that DCP-LA exhibits an antiaging effect on the skin.

\section{Materials and Methods}

\section{Cell Culture}

Normal human dermal fibroblasts were purchased from Lonza (Verviers, Belgium). Cells were grown in $\mathrm{FGM}^{\mathrm{TM}}-2$ BulletKit ${ }^{\mathrm{TM}}$ (Lonza) in a humidified atmosphere of $5 \% \mathrm{CO}_{2}$ and $95 \%$ air at $37^{\circ} \mathrm{C}$. Fibroblasts with $3-5$ passages after initial culture were used for experiments.

Epidermal keratinocytes were prepared from HR-1 mouse skin using $1.5 \%$ dispase overnight at $4^{\circ} \mathrm{C}$. After mechanical dissociation, cells were grown in Dulbecco's modified Eagle's medium sup- plemented with $10 \%(\mathrm{v} / \mathrm{v})$ fetal bovine serum, penicillin (final concentration, $100 \mathrm{U} / \mathrm{ml}$ ), and streptomycin (final concentration, 0.1 $\mathrm{mg} / \mathrm{ml})$ in a humidified atmosphere of $5 \% \mathrm{CO}_{2}$ and $95 \%$ air at $37^{\circ} \mathrm{C}$. Keratinocytes (passage 3 ) were used for experiments.

\section{$\beta$-Gal Staining}

Cells were fixed with $2 \%(\mathrm{w} / \mathrm{v})$ paraformaldehyde for $5 \mathrm{~min}$ and incubated with fresh SA- $\beta$-Gal staining solution $(1 \mathrm{mg} / \mathrm{ml} 5$-bromo-4-chloro-3-indolyl $\beta$-D-galactopyranoside, $5 \mathrm{~mm}$ potassium ferrocyanide, $5 \mathrm{~mm}$ potassium ferricyanide, $150 \mathrm{mM} \mathrm{NaCl}, 2 \mathrm{mM}$ $\mathrm{MgCl}_{2}$, and $40 \mathrm{mM}$ trisodium citrate, $\mathrm{pH} 6.0$ with $\mathrm{NaH}_{2} \mathrm{PO}_{4}$ ) for $4 \mathrm{~h}$ at $37^{\circ} \mathrm{C}$. SA- $\beta$-Gal-reactive cells were visualized with an inverted microscope (Ti-E; Nikon, Tokyo, Japan).

\section{Assay of Cell Viability}

Cellviabilitywasassayedusing3-(4,5-dimethyl-2-thiazolyl)-2,5diphenyl-2H-tetrazolium bromide (MTT) using a method described previously [22]. MTT-reactive cells were quantified at an absorbance of $570 \mathrm{~nm}$ using a microplate reader (SpectraMax Plus 384; Molecular Devices, Sunnyvale, Calif., USA).

\section{Statistical Analysis}

Statistical analysis was carried out using Dunnett's test and unpaired $t$ test. 


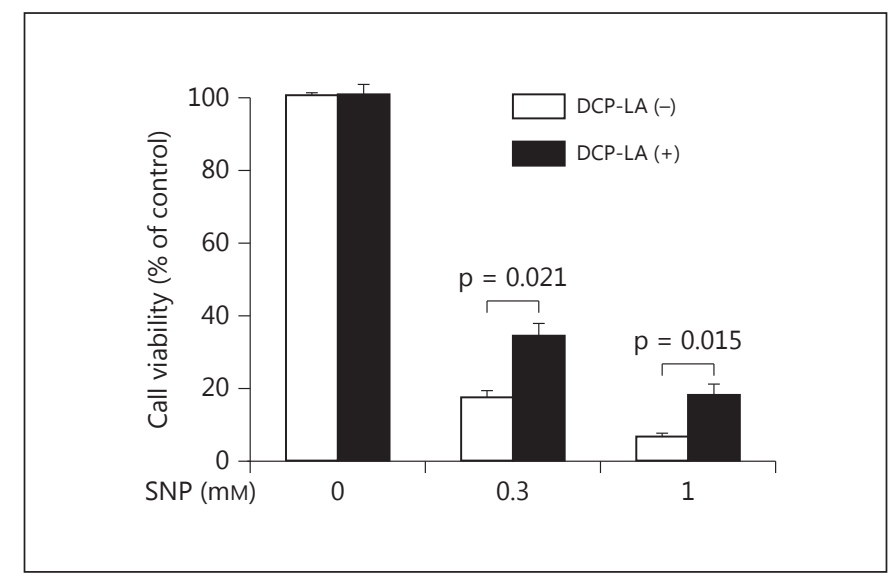

Fig. 2. DCP-LA prevents SNP-induced death of keratinocytes. Cultured mouse keratinocytes were treated with DCP-LA (100 $\mathrm{nM}$ ) in the presence and absence of SNP at the concentrations indicated for $24 \mathrm{~h}$, followed by MTT assay. Data represent the mean $( \pm$ SEM) percentage of basal MTT intensities for cells without treatment with DCP-LA in the absence of SNP $(n=4$ independent experiments). $\mathrm{p}$ values: unpaired $\mathrm{t}$ test.

\section{Results and Discussion}

The nitric oxide $(\mathrm{NO})$ donor sodium nitroprusside (SNP) produces $\mathrm{NO}_{3}{ }^{-} / \mathrm{NO}_{2}{ }^{-}$to induce $\mathrm{NO}$ stress (oxidative stress). One would think that $\mathrm{H}_{2} \mathrm{O}_{2}$ treatment is more physiological to induce oxidative stress than SNP treatment. We have confirmed that SNP induces oxidative stress, thereby activating caspase- 3 and -9 responsible for neuronal cell death, and that DCP-LA neutralizes the effect of SNP [21]. To induce oxidative stress, therefore, SNP was used in the present experiments. SNP markedly increased the numbers of SA- $\beta$-Gal-positive cells in cultured human fibroblasts and mouse keratinocytes compared to non-SNP-treated control cells (fig. 1a, b). DCPLA significantly neutralized the effect of SNP in both cell types (fig. 1a, b), which indicates that DCP-LA restores oxidative stress-induced skin aging.

SNP apparently reduced cell viability in cultured mouse keratinocytes in a concentration (0.3-1 mM)-dependent manner, and DCP-LA significantly prevented SNP-induced death of keratinocytes (fig. 2). This indicates that DCP-LA protects keratinocytes from oxidative stress-induced death. Overall, these results interpret that DCP-LA has the potential to suppress oxidative stressinduced skin aging.

So far, a number of antiaging drugs and compounds for the skin has been provided. Some hormones and com- pounds such as $17 \beta$-estradiol, aldosterone, and mineralocorticoid receptor antagonists, which are implicated in the synthesis and modulation of elastin, may exhibit an antiaging effect on the skin $[23,24]$. DCP-LA serves as a direct and selective activator of protein kinase $\mathrm{C} \varepsilon[25-$ 27]. DCP-LA also activates calcium/calmodulin-dependent protein kinase II by inhibiting protein phosphatase 1 [28]. DCP-LA, alternatively, inhibits protein tyrosine phosphatase $1 \mathrm{~B}$, thereby enhancing the receptor tyrosine kinase signaling pathway relevant to Racl activation [29]. Moreover, DCP-LA activates Akt and glycogen synthase kinase $3 \beta$, which is induced by protein kinase $\mathrm{C} \varepsilon$ [30]. In this preliminary study, DCP-LA ameliorated SNP-induced degradation of extracellular elastin/elastic fibers in cultured human fibroblasts in a protein kinase $\mathrm{C} \varepsilon$ dependent manner. This effect of DCP-LA appears to be caused by a mechanism distinct from that of any other compounds previously shown. Taken together, DCP-LA may be developed as a novel antiaging compound for the skin.

\section{Conclusions}

DCP-LA inhibited the NO stress-induced increase in SA- $\beta$-Gal-positive cells and prevented NO stress-induced cell death in cultured fibroblasts and/or keratinocytes. This raises the possibility that DCP-LA may serve as an antiaging compound for the skin.

\section{Acknowledgments}

I thank Prof. Akito Tanaka (Hyogo University of Health Sciences, Kobe, Japan) for synthesizing and providing DCP-LA.

\section{Statement of Ethics}

The author has no ethical conflict to disclose.

\section{Disclosure Statement}

The author has no conflict of interest to declare. 


\section{References}

1 Yaar M, Eller MS, Gilchrest BA: Fifty years of skin aging. J Investig Dermatol Symp Proc 2002;7:51-58.

2 Chung JH: Photoaging in Asians. Photodermatol Photoimmunol Photomed 2003;19: 109-121.

3 Tiwari AK: Antioxidants: new-generation therapeutic base for treatment of polygenic disorders. Curr Sci 2004;86:1092-1102.

4 Herrling TH, Jung K, Fuchs J: Measurements of UV-generated free radicals/reactive oxygen species (ROS) in skin. Spectrochim Acta A Mol Biomol Spectrosc 2006;63:840-845.

5 Watson RE, Gibbs NK, Griffiths CE, Sherratt MJ: Damage to skin extracellular matrix induced by UV exposure. Antioxid Redox Signal 2014;21:1063-1077.

6 Rinnerthaler M, Bischof J, Streubel MK, Trost A, Richter K: Oxidative stress in aging human skin. Biomolecules 2015;5:545-589.

7 Sivanandham V: Free radicals in health and diseases. Pharmacol Online 2011;1:10621077.

8 Akasaka E, Takekoshi S, Horikoshi Y, Toriumi K, Ikoma N, Mabuchi T, Tamiya S, Matsuyama T, Ozawa A: Protein oxidative damage and heme oxygenase in sunlight-exposed human skin: roles of MAPK responses to oxidative stress. Tokai J Exp Clin Med 2010;35: 152-164.

9 Costa C, Catania S, De Pasquale R, Stancanelli R, Scribano GM, Melchini A: Exposure of human skin to benzo[a]pyrene: role of CYP1A1 and aryl hydrocarbon receptor in oxidative stress generation. Toxicology 2010; 271:83-86.

10 Katiyar SK, Meeran SM: Obesity increases the risk of UV radiation-induced oxidative stress and activation of MAPK and NF- $\mathrm{KB}$ signaling. Free Radic Biol Med 2007;42:299-310.

11 Hwang IS, Kim JE, Choi SI, Lee HR, Lee YJ, Jang MJ, Son HJ, Lee HS, Oh CH, Kim BH, Lee $\mathrm{SH}$, Hwang DY: UV radiation-induced skin aging in hairless mice is effectively prevented by oral intake of sea buckthorn (Hippophae rhamnoides L.) fruit blend for 6 weeks through MMP suppression and increase of SOD activity. Int J Mol Med 2012;30:392-400.
12 Lee JK, Ko SH, Ye SK, Chung MH: 8-Oxo-2'deoxyguanosine ameliorates UVB-induced skin damage in hairless mice by scavenging reactive oxygen species and inhibiting MMP expression. J Dermatol Sci 2013;70:49-57.

13 Lee YJ, Kwon SB, Kim CH, Cho HD, Nam HS, Lee SH, Lee MW, Nam DH, Choi CY, Cho MK: Oxidative damage and nuclear factor erythroid 2-related factor 2 protein expression in normal skin and keloid tissue. Ann Dermatol 2015;27:507-516.

14 Ryu J, Kwon MJ, Nam TJ: Nrf2 and NF-кB signaling pathways contribute to porphyra334-mediated inhibition of UVA-induced inflammation in skin fibroblasts. Mar Drugs 2015;13:4721-4732.

15 Zhu X, Jiang M, Song E, Jiang X, Song Y: Selenium deficiency sensitizes the skin for UVB-induced oxidative damage and inflammation which involved the activation of p38 MAPK signaling. Food Chem Toxicol 2015; 75:139-145

16 Dimri GP, Lee X, Basile G, Acosta M, Scott G, Roskelley C, Medrano EE, Linskens M, Rubelj I, Pereira-Smith O, Peacocke M, Campisi J: A biomarker that identifies senescent human cells in culture and in aging skin in vivo. Proc Natl Acad Sci USA 1995;92:9363-9367.

17 Lee BY, Han JA, Im JS, Morrone A, Johung K, Goodwin EC, Kleijer WJ, DiMaio D, Hwang ES: Senescence-associated beta-galactosidase is lysosomal beta-galactosidase. Aging Cell 2006;5:187-195.

18 Bassaneze V, Miyakawa AA, Krieger JE: A quantitative chemiluminescent method for studying replicative and stress-induced premature senescence in cell cultures. Anal Biochem 2008;372:198-203

19 Gary RK, Kindell SM: Quantitative assay of senescence-associated $\beta$-galactosidase activity in mammalian cell extracts. Anal Biochem 2005;343:329-334.

20 Itahana K, Campisi J, Dimri GP: Methods to detect biomarkers of cellular senescence: the senescence-associated $\beta$-galactosidase assay. Methods Mol Biol 2007;371:21-31.

21 Yaguchi T, Fujikawa H, Nishizaki T: Linoleic acid derivative DCP-LA protects neurons from oxidative stress-induced apoptosis by inhibiting caspase-3/-9 activation. Neurochem Res 2010;35:712-717.
22 Kanno T, Nishimoto T, Fujita Y, Gotoh A, Nakano T, Nishizaki T: Sphingosine induces apoptosis in MKN-28 human gastric cancer cells in an SDK-dependent manner. Cell Physiol Biochem 2012;30:987-994.

23 Son ED, Lee JY, Lee S, Kim MS, Lee BG, Chang IS, Chung JH: Topical application of $17 \beta$-estradiol increases extracellular matrix protein synthesis by stimulating TGF- $\beta$ signaling in aged human skin in vivo. J Invest Dermatol 2005;124:1149-1161.

24 Mitts TF, Bunda S, Wang Y, Hinek A: Aldosterone and mineralocorticoid receptor antagonists modulate elastin and collagen deposition in human skin. J Invest Dermatol 2010; 130:2396-2406.

25 Kanno T, Yamamoto H, Yaguchi T, Hi R, Mukasa T, Fujikawa H, Nagata T, Yamamoto S, Tanaka A, Nishizaki T: The linoleic acid derivative DCP-LA selectively activates $\mathrm{PKC}-\varepsilon$, possibly binding to the phosphatidylserine binding site. J Lipid Res 2006;47:1146-1156.

26 Shimizu T, Kanno T, Tanaka A, Nishizaki T: $\alpha, \beta$-DCP-LA selectively activates PKC- $\varepsilon$ and stimulates neurotransmitter release with the highest potency among 4 diastereomers. Cell Physiol Biochem 2011;27:149-158.

27 Kanno T, Tsuchiya A, Shimizu T, Mabuchi M, Tanaka A, Nishizaki T: DCP-LA activates cytosolic PKCe by interacting with the phosphatidylserine binding/associating sites Arg50 and Ile89 in the C2-like domain. Cell Physiol Biochem 2015;37:193-200.

28 Kanno T, Yaguchi T, Nagata T, Tanaka A, Nishizaki T: DCP-LA stimulates AMPA receptor exocytosis through CaMKII activation due to PP-1 inhibition. J Cell Physiol 2009; 221:183-188.

29 Tsuchiya A, Kanno T, Nagaya H, Shimizu T, Tanaka A, Nishizaki T: PTP1B inhibition causes Rac1 activation by enhancing receptor tyrosine kinase signaling. Cell Physiol Biochem 2014;33:1097-1105.

30 Kanno T, Tsuchiya A, Tanaka A, Nishizaki T: Combination of PKC $\varepsilon$ activation and PTP1B inhibition effectively suppresses $A \beta$-induced GSK- $3 \beta$ activation and tau phosphorylation. Mol Neurobiol 2015, Epub ahead of print. 